SURVEYING FOR ENGINEERS 


\section{MACMILLAN TITLES OF INTEREST TO CIVIL ENGINEERS}

Reinforced Concrete Design 3rd Edition

Mosley and Bungey

Reinforced Concrete Design by Computer Mosley and Hulse

Civil Engineering Materials 4th Edition Jackson and Dhir

Fundamental Structural Analysis Spencer

Management of Engineering Projects Stone

Engineering Hydrology 4th Edition Wilson

Highway Design and Construction 2nd Edition Salter

Highway Traffic Analysis and Design 2nd Edition Salter

Civil Engineering Quantities Seeley

Civil Engineering Specification Seeley

Civil Engineering Contract Administration and Control Seeley

Structural Design Newton

Work Out Engineering Matėrials John

Work Out Fluid Mechanics Boxer

Guide to Soil Mechanics Bolton 


\title{
Surveying for Engineers
}

\author{
J. UREN \\ B.Sc., Ph.D., M.I.H.T. \\ W.F. PRICE \\ B.Sc., M.Sc., A.R.I.C.S. \\ Senior Lecturers \\ Department of Civil Engineering \\ Portsmouth Polytechnic
}

Second Edition

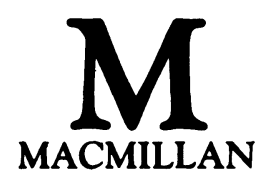


All rights reserved. No reproduction, copy or transmission of this publication may be made without written permission.

No paragraph of this publication may be reproduced, copied or transmitted save with written permission or in accordance with the provisions of the Copyright, Designs and Patents Act 1988, or under the terms of any licence permitting limited copying issued by the Copyright Licensing Agency, 90 Tottenham Court Road, London W1P 9HE.

Any person who does any unauthorised act in relation to this publication may be liable to criminal prosecution and civil claims for damages.

First published 1978 by

THE MACMILLAN PRESS LTD

Houndmills, Basingstoke, Hampshire RG21 2XS

and London

Companies and representatives

throughout the world

ISBN 978-0-333-37081-0

ISBN 978-1-349-07355-9 (eBook)

DOI 10.1007/978-1-349-07355-9

A catalogue record for this book is available

from the British Library

First edition reprinted five times

Second edition 1985

Reprinted 1986, 1987, 1988, 1989, 1990, 1991 (twice), 1992 


\section{Contents}

Preface to the Second Edition $\quad \mathrm{x}$

Acknowledgements $\quad$ xi

1. Introduction 1

1.1 The Royal Institution of Chartered Surveyors 1

1.2 Land surveying 3

1.3 Engineering surveying 5

1.4 Principles of engineering surveying 5

$\begin{array}{lll}1.5 & \text { Scale } & 6\end{array}$

1.6 Units 6

1.7 The Ordnance Survey 7

1.8 Aims and limitations of this book 11

$\begin{array}{lll}1.9 & \text { Further reading } & 11\end{array}$

2. Levelling 12

$2.1 \quad$ Levelling terminology 12

$\begin{array}{lll}2.2 & \text { Optical levels } & 14\end{array}$

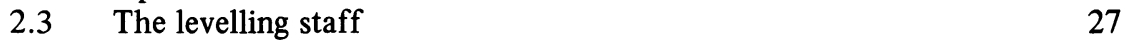

$2.4 \quad$ Principles of levelling $\quad 28$

$\begin{array}{lll}2.5 & \text { Field procedure } & 29\end{array}$

2.6 Booking and reduced level calculations $\quad 30$

$2.7 \quad$ Accuracy in levelling 33

2.8 Errors in levelling 33

2.9 Summary of the levelling fieldwork 37

$\begin{array}{ll}2.10 & \text { Additional levelling methods } \\ 2.11 & 37\end{array}$

2.11 Applications of levelling 41

2.12 Contouring 45

2.13 Further reading 51 


\section{Theodolites and their Use}

3.1 Principles of angle measurement 52

3.2 Constructional features of theodolites 53

$\begin{array}{lll}3.3 & \text { Field procedures } & 67\end{array}$

$\begin{array}{ll}3.4 & \text { Height measurement by theodolite } \\ \text { (trigonometrical heighting) } & 75\end{array}$

3.5 Adjustments of a theodolite 78

3.6 Further reading 81

3.7 Worked examples 82

4. Distance Measurement 85

4.1 Steel tapes 85

4.2 Steel taping: fieldwork and corrections 85

4.3 Steel taping: errors and accuracy 93

4.4 Steel taping: applications 95

4.5 Steel taping: worked examples 95

4.6 Other types of tape 98

4.7 Chaining 98

4.8 Optical distance measurement 99

4.9 Stadia tacheometry 100

4.10 Subtense tacheometry 104

4.11 Electromagnetic distance measurement 107

4.12 Electromagnetic waves 107

4.13 Instrument characteristics 112

4.14 EDM corrections 120

4.15 Applications of EDM to civil engineering and surveying 123

4.16 Further reading 124

$\begin{array}{ll}\text { 5. Traversing } & 125\end{array}$

5.1 Types of traverse 125

5.2 Traverse specifications and accuracy 126

5.3 Bearings and coordinates 126

5.4 Traversing fieldwork: reconnaissance 129

5.5 Traversing fieldwork: angular measurement 131

5.6 Traversing fieldwork: distance measurement 134

5.7 The three-tripod system 134

5.8 Traversing calculations 136

5.9 Plotting traverse stations 148

5.10 Whole-circle bearing and distance calculation
from coordinates

5.11 The National Grid 154

5.12 Worked examples 156

6. Triangulation and Trilateration 163

6.1 Triangulation specifications 164

6.2 Triangulation figures 164 
6.3 Triangulation fieldwork

6.4 Triangulation computations

6.5 Reduction to centre (eccentric stations)

6.6 Trilateration

6.7 Combined networks

6.8 Further reading

7. Intersection and Resection

7.1 Intersection

7.2 Resection

8. Detail Surveying and Plotting

8.1 Control networks

8.2 Drawing paper and film

8.3 Detail

8.4 Specifications for detail surveys

8.5 Locating detail

8.6 The completed survey plan

207

8.7 Computer aided plotting

209

$\begin{array}{lll}8.8 & \text { Digital terrain models (DTMs) } & 212\end{array}$

8.9 Further reading

9. Circular Curves

9.1 Types of circular curve

9.2 Terminology of circular curves

9.3 Radius and degree curves

9.4 Length of circular curves $\left(L_{\mathrm{c}}\right)$

217

9.5 Through chainage

217

$\begin{array}{ll}9.6 & \text { Design of circular curves } \\ & 219\end{array}$

9.7 Location of the intersection and tangent points in the field 220

9.8 Location of the tangent points when the intersection point is inaccessible

9.9 Setting out circular curves

9.10 Obstructions to setting out

9.11 Compound circular curves

9.12 Reverse circular curves

228

9.13 Summary of circular curves $\quad 229$

$\begin{array}{lll}9.14 & \text { Further reading } & 229\end{array}$

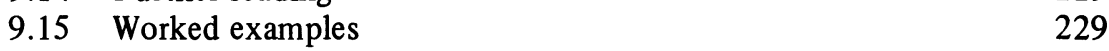

10. Transition Curves 236

$\begin{array}{lll}10.1 & \text { Radial force and design speed } & 236\end{array}$

$\begin{array}{lll}10.2 & \text { Superelevation } & 237\end{array}$

10.3 Current Department of Transport design standards 239

$\begin{array}{lll}10.4 & \text { Use of transition curves } & 241\end{array}$

10.5 Length of transition curve to be used $\left(L_{\mathrm{T}}\right) \quad 242$ 
10.6 Type of transition curve to be used 243

$\begin{array}{lll}10.7 & \text { The clothoid } & 244\end{array}$

$\begin{array}{lll}10.8 & \text { The cubic parabola } & 246\end{array}$

$\begin{array}{ll}10.9 \text { Choice of transition curve } & 249\end{array}$

$\begin{array}{ll}\text { 10.10 The shift of a cubic parabola } & 249\end{array}$

10.11 Setting out a composite curve by traditional methods 252

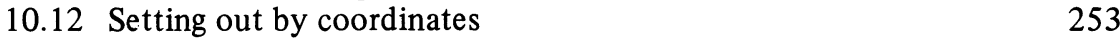

10.13 A design method for a composite curve 255

$\begin{array}{ll}10.14 \text { Wholly transitional curves } & 257\end{array}$

$\begin{array}{ll}10.15 \text { Summary of horizontal curve design } & 259\end{array}$

$\begin{array}{ll}10.16 \text { Computer aided road design } & 259\end{array}$

$\begin{array}{ll}10.17 \text { Further reading } & 261\end{array}$

$\begin{array}{ll}10.18 \text { Worked examples } & 262\end{array}$

11. Vertical Curves 273

$\begin{array}{lll}11.1 & \text { Gradients } & 273\end{array}$

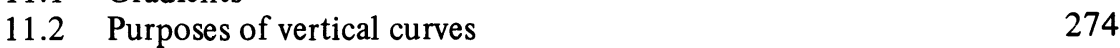

$\begin{array}{ll}11.3 \text { Type of curve used } & 275\end{array}$

$\begin{array}{lll}11.4 & \text { Assumptions made in vertical curve calculations } & 275\end{array}$

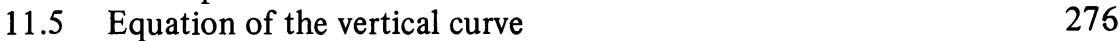

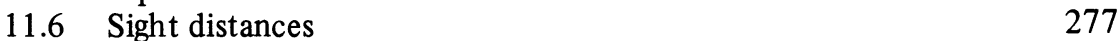

$\begin{array}{ll}11.7 K \text {-values } & 279\end{array}$

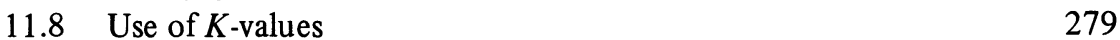

$\begin{array}{ll}11.9 & \text { Length of vertical curve to be used } \\ 11.10 & 281\end{array}$

$\begin{array}{ll}11.10 \text { Setting out the vertical curve } & 281\end{array}$

11.11 Highest point of a crest, lowest point of a sag 283

$\begin{array}{ll}11.12 \text { Summary of vertical curve design } & 283\end{array}$

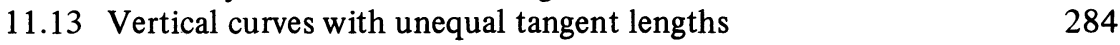

$\begin{array}{ll}11.14 \text { Computer aided road design } & 285\end{array}$

$\begin{array}{lll}11.15 & \text { Further reading } & 285\end{array}$

$\begin{array}{ll}11.16 \text { Worked examples } & 285\end{array}$

12. Calculation of Areas and Volumes 290

12.1 Calculation of plan areas 290

$\begin{array}{ll}\text { 12.2 Calculation of cross-sectional areas } & 297\end{array}$

$\begin{array}{ll}12.3 \text { Calculation of volumes } & 309\end{array}$

$\begin{array}{lll}12.4 & \text { Worked examples } & 318\end{array}$

13. Mass Haul Diagrams

13.1 Formation level and the mass haul diagram 323

$\begin{array}{ll}13.2 & \text { Drawing the diagram } \\ 13.323\end{array}$

$\begin{array}{lll}13.3 & \text { Terminology } & 325\end{array}$

$\begin{array}{ll}\text { 13.4 Properties of the mass haul curve } & 325\end{array}$

13.5 Economics of mass haul diagrams 326

$\begin{array}{ll}13.6 & \text { Choice of balancing line } \\ 13.7 & 329\end{array}$

13.7 Uses of mass haul diagrams 333 
14. Setting Out 335

14.1 Personnel involved in setting out and construction 336

$\begin{array}{lll}14.2 & \text { Aims of setting out } & 337\end{array}$

$\begin{array}{lll}14.3 & \text { Important considerations } & 337\end{array}$

$\begin{array}{lll}14.4 & \text { Stages in setting out } & 338\end{array}$

$\begin{array}{lll}14.5 & \text { Preliminaries to setting out } & 339\end{array}$

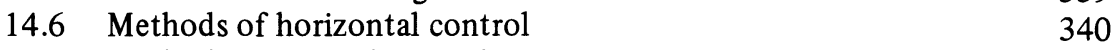

$\begin{array}{lll}14.7 & \text { Methods of vertical control } & 344\end{array}$

$\begin{array}{lll}14.8 & \text { Positioning techniques } & 351\end{array}$

14.9 Setting out a pipeline 354

14.10 Setting out a building to ground-floor level 358

14.11 Transfer of control to ground-floor slab 359

$\begin{array}{ll}14.12 \text { Setting out formwork } & 359\end{array}$

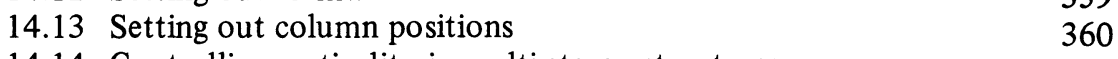

14.14 Controlling verticality in multi-storey structures 360

14.15 Transferring height from floor to floor 364

$\begin{array}{ll}\text { 14.16 Setting out using laser instruments } & 365\end{array}$

$\begin{array}{ll}\text { 14.17 Applications of setting out from coordinates } & 372\end{array}$

$\begin{array}{ll}14.18 \text { Accuracy of setting out } & 376\end{array}$

$\begin{array}{ll}14.19 \text { Further reading } & 378\end{array}$

$\begin{array}{ll}14.20 \text { Worked examples } & 379\end{array}$

$\begin{array}{lr}\text { Index } & 383\end{array}$ 


\section{Preface to the Second Edition}

In the seven years that have passed since the publication of the first edition of Surveying for Engineers there have been several developments in engineering surveying, particularly in Electromagnetic Distance Measurement (EDM), microcomputers, data processing and in the acceptance of the need for a greater degree of control when setting out engineering works.

Consequently, when compiling this second edition, we have attempted to keep in step with current attitudes and, although the style of the book remains the same, several significant changes have been made.

The optical levels and levelling chapters have been combined as have the three distance measurement chapters. Much of the optical distance measurement material has been removed since such equipment and methods have been largely superseded by EDM techniques.

New chapters have been introduced dealing with triangulation, trilateration, intersection and resection since engineers are coming into contact with these techniques to a much greater extent than was the case in the past.

Within existing chapters, many amendments and changes have been incorporated. The setting-out chapter has been extended since this topic has gained in importance in recent years. The new Department of Transport design standards for highways are discussed in the curve chapters, trigonometrical heighting is introduced into the theodolites chapter, computerised plotting methods are discussed in the detail surveying chapter and more worked examples have been included throughout the book.

An introductory chapter has been added to provide a background to the subject and a guide to the professional and government bodies which are involved in surveying.

Although the book has been written with civil engineering students in mind, it is hoped that it will also be found useful by practising engineers as well as by any other students who undertake engineering surveying as a subsidiary subject.

The text covers engineering surveying up to the end of virtually all first-year and most second-year degree, diploma and BTEC courses in civil engineering, engineering geology, geography, surveying and other related disciplines at universities, polytechnics and colleges of technology. Other courses for which it is thought useful are $\mathbf{O}$ and $\mathbf{A}$ level surveying and the professional examinations of the various civil engineering related institutions. 


\section{Acknowledgements}

The authors wish to thank all those who have contributed in any way to the preparation of this book and, in particular, the following persons and organisations.

Mr J. R. Smith and Mr P. F. Gardner, two of our colleagues at Portsmouth Polytechnic, for their considerable help and advice when reading and criticising the original draft.

Mr P. A. Stead, Head of the Department of Civil Engineering at Portsmouth Polytechnic.

The photographic section at Portsmouth Polytechnic and, in particular, Mr K. Purdy, for considerable help with many of the photographs.

The British Standards Institution for permission to publish table 14.1 which is reproduced from the British Standard Code of Practice on Accuracy in Building, BS 5606.

The Building Research Establishment and, in particular, its Director, for permission to publish figures 4.5 and 4.6 which are Crown copyright and are reproduced from BRE Digest 114.

The Construction Industry Research and Information Association for permission to reproduce figures $14.7,14.11,14.17$ and 14.53 which are taken from The CIRIA Manual of Setting Out Procedures.

The Department of Transport for permission to publish tables 10.1 and 11.1 and figures 11.4 and 11.5 .

Geotronics (UK) Ltd and, in particular, Mr B. McGuigan, for providing figures $4.22 a, 4.25,4.27$ and 4.28 .

Hall and Watts Ltd for providing figure 4.27.

The National Swedish Institute for Building Research and, in particular, Dr John van den Berg, for permission to reproduce figures 14.5, 14.14, 14.16, $14.18,14.19,14.31,14.32,14.33,14.34,14.35,14.37,14.38,14.39,14.40$, $14.41,14.42$ and 14.43 .

The Ordnance Survey for providing material reproduced in figure 6.3 and section 1.7 .

The Property Services Agency, Central Survey Branch, Department of the Environment and, in particular, Mr S. G. Taylor, for providing figures 8.6, 8.8, 8.9 and 8.10 .

The Royal Institution of Chartered Surveyors for providing material on which figures 1.1 and 1.2 and sections 1.1 and 1.2 are based.

Smail Sons and Co. Ltd for providing figure 12.8. 
Spectra Physics Ltd and, in particular, Mr A. Middlemas, for providing figures $14.46,14.47,14.49,14.51$ and 14.52 .

The Survey and General Instrument Co. Ltd for obtaining permission from

Kern and Co. Ltd to publish figures $2.13 a, 3.3 b, 3.7,3.18,4.22 b, 4.24$ and 4.26.

Tellumat Ltd for providing figure 4.19.

Wild Heerbrugg (UK) Ltd and, in particular, Mr B. C. N. Snelling, for permission to publish figures $2.9,2.12,2.13 b, 3.3 a, 3.6,3.8,3.9,3.10,3.13$, $3.16,3.17,3.18,4.14,4.26,4.28$ and 14.44 . 